\title{
Possibilities for Technology-enhanced Active Learning of Structural Steel De- sign
}

\section{Dr. Ryan L. Solonsky P.E., Pennsylvania State University, University Park}

Ryan Solnosky is an Assistant Teaching Professor in the Department of Architectural Engineering at The Pennsylvania State University at University Park. Dr. Solnosky started at Penn State in July of 2013 and has taught courses for Architectural Engineering, Civil Engineering, and Pre-Major Freshman in Engineering. He received his integrated Professional Bachelor of Architectural Engineering/Master of Architectural Engineering (BAE/MAE) degrees in architectural engineering from The Pennsylvania State University, University Park, PA, in 2009, and his Ph.D. in architectural engineering from The Pennsylvania State University, University Park, PA in 2013. Dr. Solnosky is also a licensed Professional Engineer in PA. His research interests include: integrated structural design methodologies and processes; Innovative methods for enhancing engineering education; and high performing wall enclosures. These three areas look towards the next generation of building engineering, including how systems are selected, configured and designed. 


\title{
Possibilities for Technology Enhanced Active Learning of Structural Steel Design
}

\begin{abstract}
Students entering college settings are: increasingly computer literate, users of digital technologies, visually driven, and have been exposed to active learning styles in high schools. Notions of technology, visual learners, and engaging environments are directly and indirectly shaping how we are expected to teach. When students are asked their preferences in classroom learning, the author has noticed that responses vary with preferences for PowerPoint slides, chalkboard notes, projects, flipped classrooms and utilization of computer software. Based on these common and upcoming learning mechanisms, the author is experimenting with implementing different techniques in a structural steel design class offered to undergraduates. This course is a $4^{\text {th }}$ year senior-level steel design type class that educates Architectural Engineering students specifically about the fundamentals and practicality of designing steel structures for gravity loading according to AISC.

The test bed for this study looks into various techniques based on segmenting topics into different styles for teaching evaluation. The varied educational styles tested included: flipped classrooms with light board videos, real project discussions / decompositions with solstice pods displays, enhanced white boards with projected digital images, mini-team design charrettes on smartboards, and traditional chalk lecturing as a baseline. These techniques are being explored to deepen student comprehension of why and how building structural steel systems are the way they are. It was hypothesized that by developing active strategies coupled with technology will better that engage and heighten student-learning outcomes over more traditional methods. To evaluate the effectiveness of these methods, descriptive and statistical methods will be employed through pre-and post-surveys and interviews along with grade performance correlation.
\end{abstract}

\section{Introduction}

Present day students in college are increasingly computer literate (Fox et al. 2009; DeGrazia et al. 2012), heavy users of digital technologies (Moon 2010), are more visually driven/stimulated (Grant et al. 2009), and have been exposed to more active learning styles in high schools (Glover et al 2007). Such scenarios and attributes that encompass technology, visual learning, and engaging classroom environments are directly and indirectly shaping how we are expected to teach. Based on new and upcoming learning mechanisms, there exists opportunities to advance very traditionally structured curriculum in engineering, mainly structural engineering. Many of the fundamentals taught in structural engineering are well over 100+ yrs. old (classical theories), to more modern software that started 30+ yrs. ago, to even the various design methodologies that are continuously being developed today. Many of the methods used to teach structural engineering have not significantly changed over the years, based on observations by the author in reviewing civil engineering, architectural engineering, and architecture programs.

Based on the plethora of new teaching methodologies being adopted across different curriculums along with a vastness of technology available to deliver content, a study was done to start to investigate its appropriateness in structural engineering. The study presented here experiments with implementing different technology techniques in a structural steel design class offered to undergraduate architectural engineering students. This course is $4^{\text {th }}$ year senior-level design class that 
educates students specifically about the fundamentals and practicality of designing steel structures for gravity loading according to AISC (specifically applied to buildings). For comparative purposes, this class is similar in nature to most traditional civil engineering undergraduate entry structural design classes.

\section{Traditional Structural Engineering Status Quo}

According to sources such as U.S. DOE (2001) and Young et al. (2012), traditional structural engineering instruction within classrooms more often than not take a hands-off approach that transmits information statically and with little appeal. Typical techniques include (Moon 2010) those grouped and listed in Table 1.

Table 1: Examples of Traditional Instruction Techniques

\begin{tabular}{|l|l|}
\hline \multicolumn{1}{|c|}{ Group Type } & \multicolumn{1}{c|}{ Traditional Techniques } \\
\hline Conveying Notes & $\begin{array}{l}\text { Transparencies } \\
\text { White and black boards notes that student copies } \\
\text { PowerPoint slides that are completely filled in } \\
\text { PowerPoint slides that contain filled in the blank slots } \\
\text { Packets that contain filled in the blank slots with a tablet writing used }\end{array}$ \\
\hline Examples & $\begin{array}{l}\text { Implement examples from the textbook } \\
\text { Ideal in nature (for design they are isolated members) } \\
\text { Simplified configurations that don't cover the full range of provisions } \\
\text { "Non-relevant" complex examples (configurations rarely found in actual use) } \\
\text { Isolated examples that exclude other disciplines }\end{array}$ \\
\hline Assignments & $\begin{array}{l}\text { Textbook Readings } \\
\text { Codes and Standards Readings (i.e. AECE 7, IBC, AISC, etc.) } \\
\text { Homework problems from the book } \\
\text { Homework problems from faculty } \\
\text { Closed or open note quizzes } \\
\text { Closed or open note exams } \\
\text { Idealized Projects }\end{array}$ \\
\hline
\end{tabular}

These "chalk and talk" format methods often confine learning that minimizes student engagement with the topic resulting in little more than surface learning (Walther et al. 2011). According to Bernould (2005), engineering students overwhelmingly (85-95\%) preferred passive, lecture-based instruction with plenty of homework exercises. There is evidence that students in these cases have not been exposed to strategies that are more active and/or the context of the topic is such that details are only highlighted. Rafiq (2010) has found that passive lecturing produces student fixation on number crunching instead of more critical ideas related to creative and integrative applications within design. Supporting evidence can be seen back in a 1978 study by Hartley and Davie where learners can recall $70 \%$ of the first 10 minutes of a lecture yet they only remember $20 \%$ of the remainder. This could explain the large amount of assignments students request as they are truely learning (for the first time) as they are doing the assignments.

While structural engineering is vast and varying topic wise, there exists common themes that must be taught in all structural engineering classes. The most basic of categories are: structural analysis and structural design. Lectures and assignments fall into and align with one of the three main structural sub-groups: 1) the fundamental theory, 2) application of the theory to practical, and 3) code interpretations.

Depending on the curriculum and the faculty teaching structural classes, these three sub-groups are often disconnected from the larger picture of structural systems in projects. An attribute of this can 
be seen by traditional representations of structures used in homework and exams (Figure 1). Aparicio and Ruiz-Teran (2007) and Phelps et al. (2008) agree and place the blame on homework and the application of projects as being "oversimplified when compared to problems engineers deal with in practice." As such, it is difficult to develop realistic and innovative solutions in the classroom due to traditional reliance on pedagogical approaches mired in lower-order cognitive skills (Schokker and Scanlon 2001).

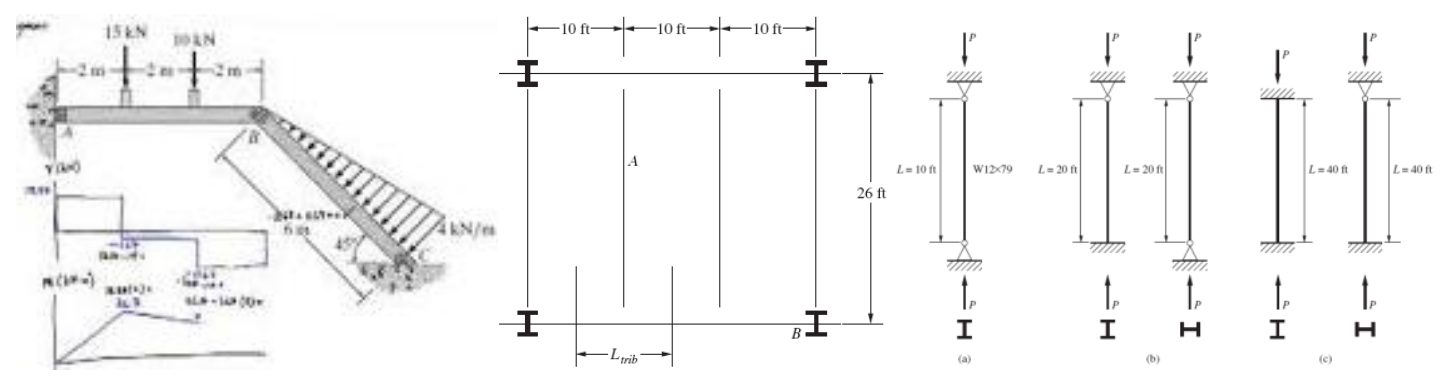

Figure 1: Traditional Education Materials (taken from dept. course handouts)

Often ill-constructed problems are commonly used that demand neither active participation nor higher order cognitive skills (Savin-Baden 2003; Boud and Feletti 1997). Back in 2008, ASCE (2008) along with Andersen et al. (2007), observations revealed that many engineering students do not know how to approach large complex systems due to their exposure to idealistic examples. Additionally they not capable of providing critical multi-disciplinary integration of their designs due to the isolated nature of topics in the classroom.

\section{Technology as a New Medium}

Rafiq back in 2010 observed that $21^{\text {st }}$ century students are starting to demand highly supported and active learning environments. It needs to be acknowledged that engineering programs are already tightly packed allowing little time for extra investigation into new topics. An advantage to using technology as a medium for learning is that the content does not change just the delivery and approach of the content. If technology permits new education on class topics, Dymond and Swenty (2017) provide reason to change the material viewpoints to be more collaborative and have myriad of challenges more closely matching the profession (Abbott and Penney 2016).

With the rapid development of design tools there has been an improvement in quickening thought-to-product cycles that can positively allow faculty to grow design thinking (Bruhl et al. 2017; Davis 2012). Flipped classrooms inherently have adopted forms to technology such as: interactive instructional videos, in-class learning activities with digital media, and detailed in class emersion scenarios (Johnson et al. 2013; Margulieux et al. 2014; Kwuimy et al. 2017; Fogart 2017).

When technology is done correctly, classrooms can transform from teacher-centered to a student-centered environment. When successful positive results has been observed such as (Means 2009; Prince 2004): better knowledge retention, greater persistence, improved class attendance, strong and more accurate implementation of materials. As technology is reshaping the academic experience, engineering needs to examine expectations and evaluate the role of delivery strategies, including structural engineering (Penrod 2005; Schmidt et al. 2017). In developing courses to implement technology, care needs to be taken to ensure dilution of a topic doesn't happen merely for the sake of the technology or based on the instructor experience. 


\section{Structural Steel Design Possibilities for Technology Enhanced Active Learning}

Structural engineering in today's practice does implement a substantial amount of technology. This is largely due to the complexity of the projects, demands of the owner(s) and other designers, and the current trends in the industry to adopt and implement technology. If we look at the last several years of the NASCC conference presentations, software trends in the industry can be seen (Table 2). If we look into recent educational technologies that are being tried in other disciplines, we can find trends there also (Table 2).

Table 2: Relevant Types of Technology found in the Profession and Academia.

\begin{tabular}{|l|l|}
\hline \multicolumn{1}{|c|}{ Use group } & \multicolumn{1}{c|}{ Trending Types of Technology } \\
\hline Profession & $\begin{array}{l}\text { - Software for analyzing and design structural steel gravity and laterals systems } \\
\text { - BIM software for coordinating the design with other disciplines and in generating structural } \\
\text { drawings }\end{array}$ \\
& $\begin{array}{l}\text { - Detailing software to design connections } \\
\text { - IT technologies to communicating and collaborating with other design professionals. }\end{array}$ \\
\hline Education & $\begin{array}{l}\text { - Video-Conferencing with industry professionals in capstone settings } \\
\text { - Immersive displays/ environments to show projects at true scale }\end{array}$ \\
& $\begin{array}{l}\text { - Education game software that take students non-linearly through a scenario that educates } \\
\text { - Fiscussion Boards where students comment to one-another to with outside professionals }\end{array}$ \\
& - 3D printers to physically grasp design solutions \\
& - Interactive smart touch technology to manipulate and interact with media \\
\hline
\end{tabular}

If consideration and careful planning is given to a steel course's structuring, it is possible to mix these two groups of technology together for engineering education practices. The first area to start with is what topics in structural steel educations lends itself to nicely technology. Here, behavior and design can be simulated on software programs alongside hand calculations. Additionally, designs can be documented and coordinated with other disciplines (within a building) to look at the larger context of structures. Potential theorized opportunities are documented in Table 3.

Table 3: Steel Topics, Teaching Opportunities, and Teaching Intents

\begin{tabular}{|c|c|c|c|}
\hline Theme & Relevant Steel Topic & Steel Design Opportunity & Intent of the Teaching \\
\hline $\begin{array}{l}\text { Component / } \\
\text { Element } \\
\text { Design }\end{array}$ & $\begin{array}{l}\text { - Compression Members } \\
\text { - Tension Members } \\
\text { - Bending Members } \\
\text { - Combine Members } \\
\end{array}$ & $\begin{array}{l}\text { - Use the software to design the elements } \\
\text { and then verify with hand checks } \\
\text { - Simulation of behavior through FEA }\end{array}$ & $\begin{array}{l}\text { - Identify critical elements } \\
\text { - Identify poorly designed elements } \\
\text { - Develop an understanding of important } \\
\text { design requirements }\end{array}$ \\
\hline System Design & $\begin{array}{l}\text { - Gravity systems } \\
\text { - Laterals Systems }\end{array}$ & $\begin{array}{l}\text { - Clash detection with other disciplines and } \\
\text { your designs. } \\
\text { - Compare multiple design models against } \\
\text { one another } \\
\text { - Document designs in model content }\end{array}$ & $\begin{array}{l}\text { - Develop a better understanding } \\
\text { surrounding systems and their impact } \\
\text { on the design } \\
\text { - Identify poorly designed systems } \\
\text { - Relay the importance of repetition and } \\
\text { constructability }\end{array}$ \\
\hline
\end{tabular}

The second area of technology that was considered was to use interactive media and mechanisms to have students interact more with the topics. Video lectures, simulations, online discussions, and touch technology allow for more active engagement and can feasibility be used for any steel topic. Both sets of notions and opportunities were looked at from a larger perspective for the research study presented here. Specific details are documented in the next section. 


\section{Research Study Design}

This early pilot research study is grounded in constructivist theory. The test bed for this study looked into various technologies and their effectiveness in impacting learning. The varied styles include: enhanced board interactions, flipped classrooms, real project discussions through technologies, and mini-team design charrettes. These techniques were explored in an attempt to 1) deepen student comprehension of why and how building structural steel systems are the way they are and 2) to better engage the students. The author hypothesizes that by developing technology enhanced lectures will better that engage and heighten student learning outcomes over more traditional methods.

\section{Class Composition}

The goal of Architectural Engineering's first steel design class (AE 401) is threefold: 1) take on the role of a designer and create structural solutions in steel, 2) apply knowledge to evaluate limit states to see if members that were designed have sufficient capacity, and 3) prepare you for advanced systems design. To meet these goals the specific learning objectives were:

- Understand and interpret the organization and use of the AISC Manual of Steel Construction

- Identify and apply appropriate steel provisions (AISC) to elements and systems.

- Design steel members using the Load and Resistance Factor Design (LRFD) approach.

- Develop skills in completing and checking individual component and complete structural system designs.

Due to the volume of possible topics that AISC incorporates within the Specification, the topical list for AE 401 was selected to be reflected of most standard entry level undergraduate steel design classes. Due to our mandatory two steel classes in the undergraduate AE program, no lateral members or systems are discussed. Instead, AE 401 is gravity focused while the advanced class is lateral focused. The classroom topics for Steel Design I are listed in Table 4 along with their duration and scope within structural steel according to AISC.

Table 4: Breakdown of AE 401 Topics and Durations

\begin{tabular}{|l|l|c|}
\hline \multicolumn{1}{|c|}{ Topic } & \multicolumn{1}{c|}{ Scope } & $\begin{array}{c}\text { Duration } \\
\text { (\# of classes) }\end{array}$ \\
\hline Steel Systems and Materials & AISC shapes and materials & 2 \\
\hline Intro to Codes and Loads Review & IBC and ASCE 7 & 2 \\
\hline Tension Member Behavior and Design & Plates, Angles, W and WTs & 5 \\
\hline Compression Member Behavior and Design & W-Shapes & 8 \\
\hline $\begin{array}{l}\text { Non-Composite Beam Behavior and Design for } \\
\text { Flexure, Shear and Deflections }\end{array}$ & W-Shapes & 3 \\
\hline Steel Decking & Roof, Non-composite and composite & 3 \\
\hline Steel Joists and Joist Girders & K, LH, DLH Series & 7 \\
\hline $\begin{array}{l}\text { Composite Beam Behavior and Design for Flexure, } \\
\text { Shear and Deflections including studs }\end{array}$ & W-Shapes & 3 \\
\hline Conceptual Layout of Gravity Systems in Buildings & N/A & 4 \\
\hline Bolt and Weld Limit States & $\begin{array}{l}\text { Fillet and CJP welds, A325 and A490 } \\
\text { Bolts }\end{array}$ \\
\hline
\end{tabular}

This course meet three times a week for 50 minutes each time for a total of 45 meetings over the 15 week semester. No class periods are spent on exams. The utilized room (Figure 2) was a recently 
renovated classroom that incorporated two projectors, solstice pod projection capabilities, 5 smart board projectors on whiteboards, and mobile furniture for easy reconfiguration.

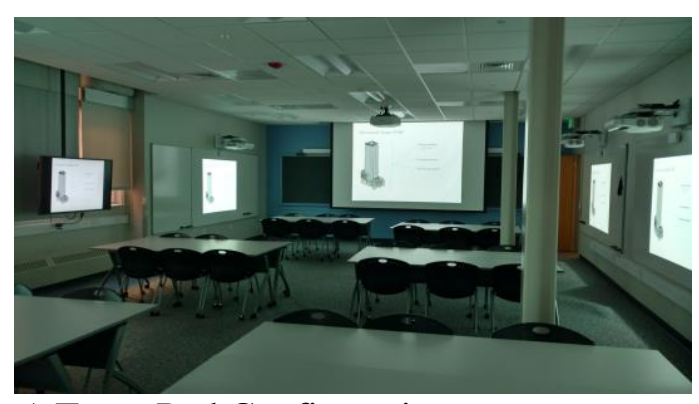

a) Team Pod Configuration

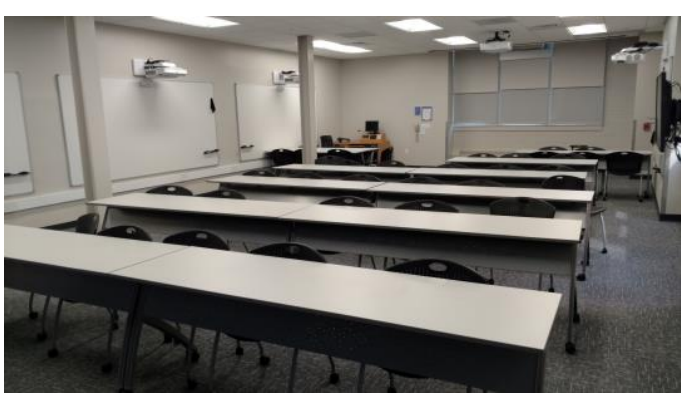

b) Traditional Lecture Configuration

Figure 2: Classroom Configurations

\section{Varied Technology Strategies}

To study the impact technology could have on learning structural steel, several approaches were investigated. As several approaches were taken, assessment was studied for each appropriate technology separately when possible. Additionally, different technology approaches were not mixed with the same topic yet assessment techniques were mixed. The correlation of technology, assessment, and topic are shown in Table 5. As Table 5 illustrates, smartboard lecture supplement materials, Solstice Pods, Flipped Classroom with Edpuzzle, and Smartboard Interactive Scenarios for design charrettes were the 4 different technologies with deployed

Table 5: Topic and Technology Strategies

\begin{tabular}{|l|l|c|}
\hline \multicolumn{1}{|c|}{ Topic } & \multicolumn{1}{|c|}{ Technology Strategy } & Assessment Method \\
\hline Steel Systems and Materials & $\begin{array}{l}\text { Solstice Pods (for Systems) } \\
\text { Supplemental Videos (for Systems) }\end{array}$ & Hwk, Quiz \\
\hline Intro to Codes and Loads Review & N/A & Hwk, Exam \\
\hline Tension Member Behavior and Design & N/A & Hwk, Exam, Project \\
\hline Compression Member Behavior and Design & N/A & Hwk, Exam, Project \\
\hline $\begin{array}{l}\text { Non-Composite Beam Behavior and Design for } \\
\text { Flexure, Shear and Deflections }\end{array}$ & N/A & Hwk, Exam, Project \\
\hline Steel Decking & Smartboard Lecture supplement & Hwk, Exam, Project \\
\hline Steel Joists and Joist Girders & Smartboard Lecture supplement & Hwk, Exam, Project \\
\hline $\begin{array}{l}\text { Composite Beam Behavior and Design for } \\
\text { Flexure, Shear and Deflections including studs }\end{array}$ & Flipped Classroom with Edpuzzle \\
\hline $\begin{array}{l}\text { Conceptual Layout of Gravity Systems in } \\
\text { Buildings }\end{array}$ & $\begin{array}{l}\text { Smartboard Interactive Scenarios } \\
\text { Model exploration }\end{array}$ & Class scenarios, Project \\
\hline Bolt and Weld Limit States & N/A & Exam \\
\hline
\end{tabular}

Each of these technologies will now be discussed in their own subsection to understand their composition.

\section{$\underline{\text { Smartboard Lecture Supplement Materials }}$}

To enhance the usage and familiarity of the AISC manual along with Deck and Joist Catalogs, a smartboard/whiteboard technology was tested that permitted easy examples to be shown and interacted with (Figure 3). As the smart board projector displays on the whiteboard, design tables were shown alongside examples being calculated. During the example, table manipulation and interaction 
could easily be done that was superior to having students refer to handout or notes while the problem was conducted.

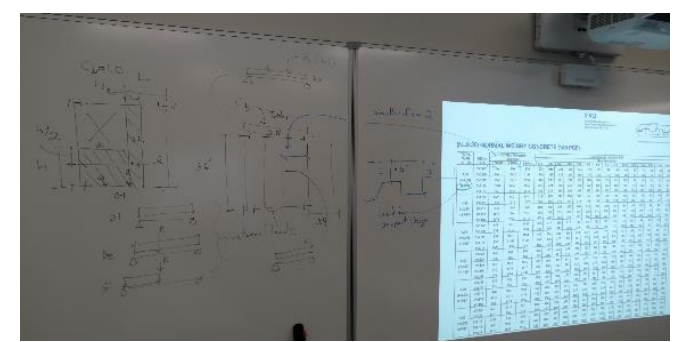

Figure 3: Enhanced whiteboard projection example

\section{$\underline{\text { Smartboard Interactive Scenarios for Design Charrettes }}$}

Interactive scenarios on smartboards were implemented to aid in the teaching of how to conceptually layout a steel gravity system over a 3 day period. First, students were given a 50min. lecture on best practices and considerations on how to layout structure. This lecture was based on instructor experience, IBC requirements, and AISC published works from Modern Steel Construction. The remaining two days were then spend having students in teams (4-5 per team) draw layouts on interactive smart boards in an effort to generate possible configurations for a steel solution to an architectural plan (Figure 4). Each scenario on the smart board consisted of students first getting a dimensioned architectural floor plan (to a real project) and asked to apply prior knowledge. After time passed ( 10min) Students were shown the real steel solution. Based on the scaling of images, student designs were able to be directly overlapped with the real solutions thus allowing for discussions on differences.

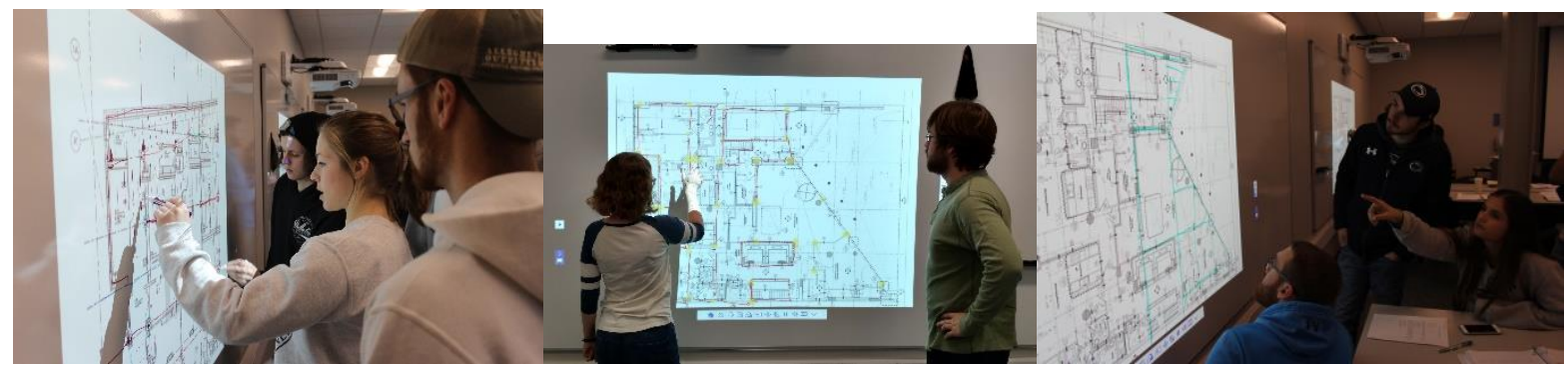

Figure 4: Examples of Interactive Smartboard Scenarios

\section{Flipped Classroom with Edpuzzle}

For composite beam systems, an inverted or "flipped" classroom setup was constructed. Here two types of technology were deployed, the first was the use of a light board to generate the video content (Figure 5a) and the second was the use of Edpuzzle.com and its attributes to distribute the video (Figure 5b). Videos were created by the instructor using a glass light board to record color coordinated lecture notes on composite beam fundamentals with instructor audio discussions. Initial videos were inverted due to their method of creation but were formatted in video editing software and stitched together. While typical classroom flip recommends 5 to 15 minute videos, these videos were between 10-20mins so that a single topic (within composite beams) could be self-contained. 


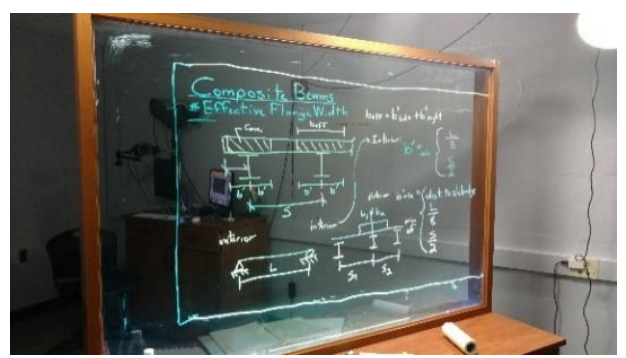

a) Light Board Setup

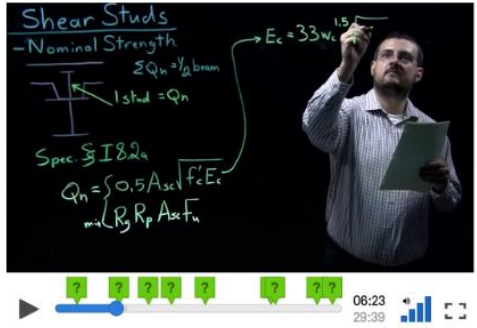

b) Video in Edpuzzle.com

Figure 5: Classroom Flip with Light board Technology

Edpuzzle.com was implemented to distribute the videos. This site was selected in that the instructor could track each students' progress in the videos, as well as, the number of times each student watched various sections of the video. To ensure videos were watching, low-level assessment questions were asked and counted as part of their class participation grade. Everyone in the class was informed that they must copy the material presented if they want access to it on exams or in the future as students were not given PowerPoint slides or the notes on what was being discussed.

Aligning with the notion of a flipped classroom, supplemental video lectures were also tested. Here video recordings presented at prior AISC NASCC conferences were given to students to watch through Edpuzzle.com. While there is a multitude of videos available on the AISC website, real project discussions were utilized to show how steel solutions were created and incorporated into buildings. Two of these projects were given in the piloting. After the videos were due, a short 10min discussion was done in class to relate to our materials and answer student questions.

\section{$\underline{\text { Solstice Pods }}$}

One technology available in the classroom was Solstice pods. With the pods, multiple participants can share and control content from their laptops and mobile devices on the in-room displays. As a result, it can permit facilitating round-table discussions, groups presenting in-class work, or sharing multiple images all in real-time. Solstice pods in the provided classroom consisted of 5 boards can share 8 devices each, all of which the faculty member controls which image is projected the largest. In implementing this technology, students were randomly selected to project up case study articles from either Structure Magazine or Modern Steel Construction on a project of interest and summarize the article in 2-3mins.

\section{Demographics}

AE 401 was composed of a total of 22 students, 5 were female and 17 were male. From an ethnic standpoint, 19 were Caucasian, 1 was African American, and 2 were Chinese. All students were $4^{\text {th }}$ year standing in 5 year program. None of the 22 students had taken steel design previously and all were architectural engineering majors.

\section{Study Assessment Strategy}

To assess impact of the technology methods, a pre- and post-survey was administered. The presurvey was administered on the first day of class while the post-survey was administered on the last day of class. The survey focused on several items as bulleted below. In addition to these, open-ended questions were included to allow students to provide additional thoughts, as well as, a question that 
permitted students to rank teaching methods from best to worse. Within the three groups of questions, any question that didn't pertain to technology content, that was omitted here in the results and discussion for brevity and relevance.

- Students' perceived confidence in their ability to complete 14 different types of tasks relating to various structural steel areas

- Students' perceived level of knowledge on 20 structural steel topics

- Students' level of agreement on learning style preferences for 13 scenarios.

A total of 17 students (77.3\%) completed the pre-survey; while 15 (68.2\%) completed the postsurvey. To allow for direct comparison only pair calculations were completed (the two pre-survey only data was discarded) Confidence used a 7-point Likert scale of 1 (Cannot do at all),), to 7 (Highly certain can do). Agreement also adopted a 7-point Likert scale but stated that: 1 (strongly disagree), 4 (neither agree nor disagree), to 7 (strongly agree). Lastly for knowledge, a 10-point Likert scale of 1 (I know nothing), 4 (average knowledge), to 10 (expert level knowledge).

\section{Assessment Results}

\section{Learning Style Preferences: Perceived Notions}

Students were asked around their learning style preferences at the beginning and end of the semester. For each preference question asked, the average rating from pre- to post-survey was determined. Figure 6 shows the average rating on each of the 13 questions. Only eight learning styles had an increase in preference. While there was an increase, the amount was minimal (0.07-0.60 of a Likert scale up). Relating to the technology adopted, students did improve their rating of flipped classroom with light boards ( 0.33 avg. increase). Only 1 area dropped in preference ( -0.33 drop). This drop was related to listening to classroom faculty discussion with notes fully provided and already completed. Positively, students stated that project was a success as it provided a strong opportunity to better design and understand layouts ( $0.60 \mathrm{avg}$. increase). The project was possible in this class due to the restructuring of content with technology that primed them on how to approach projects.

If we look at the shifting of the 7-point Likert scale from Pre- to post- survey, we can see a few trends (Figure 7). For the most part the changes were minimal. The disagreement in liking blackboard notes was narrowed down. Fill in the black notes were not done in this class yet students did change to either disliking them more or liking them more (neutral band narrowed). A potential reason for this was that another structural professor was using fill-in-the-blank notes. Homework, watching videos then doing activities, and building discussions all had increases. While these shifts are minor (and mostly likely not statistically significant), these are related to the technologies adopted. Additional examples and more time to do homework in class was afforded due to the flipping and videos while the building discussions used the Solstice pods. 


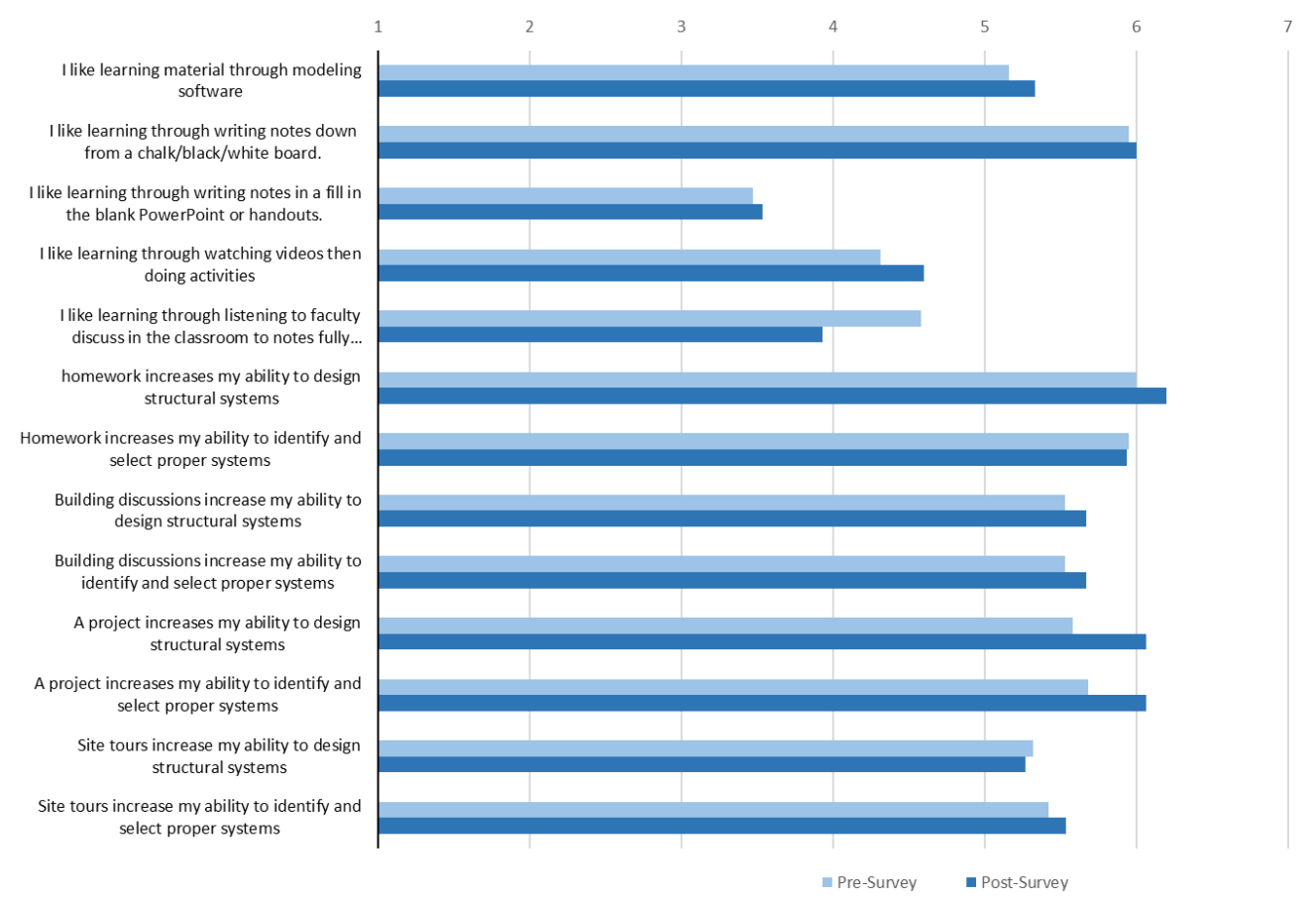

Figure 6: Comparative Average plots for learning style preferences

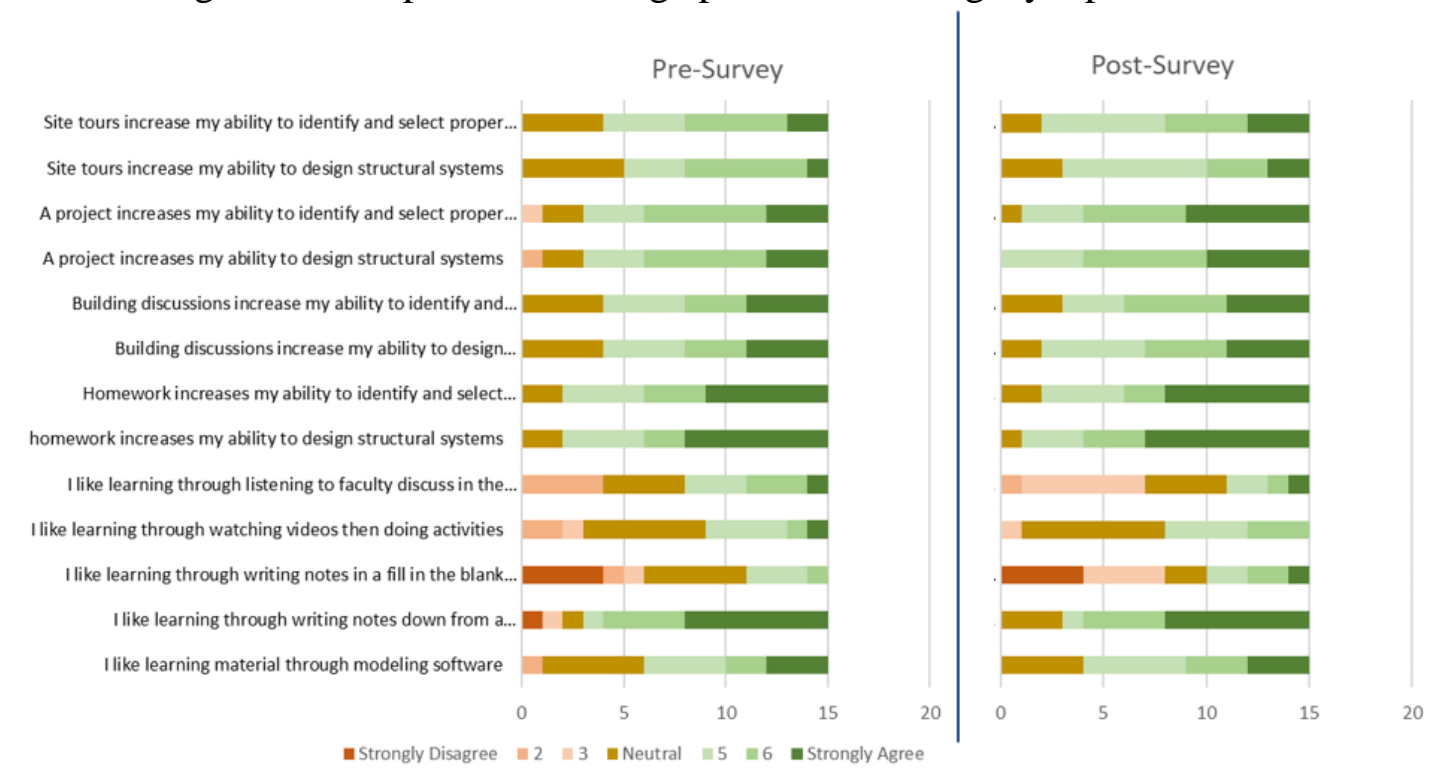

Figure 7: Likert Scale Response Changes for Learning Style Preferences

\section{Ranking Teaching Methods}

At the end of the semester, students were asked to rank six teaching methods that were adopted in the class (Figure 8). Board notes were still the $1^{\text {st }}$ preferred method of learning content as compared to the other methods. The next top preference was modeling the project (used Navisworks to show design interactions and system decomposition). Pod discussions were largely (40\%) selected as the least favorite method. In regards to flipped classrooms, students didn't seem to mind watching the edpuzzle videos. In total three types of videos were shown: light board (Figure 5), industry videos, and 
then voice over by the instructor. Of the three, $73.3 \%$ had the light board as the first choice if they had to watch more. Instructor voice over had the $2^{\text {nd }}$ choice highest amount $(60 \%)$. In last choice $\left(3^{\text {rd }}\right)$ was the AISC NASCC videos with (60\%).

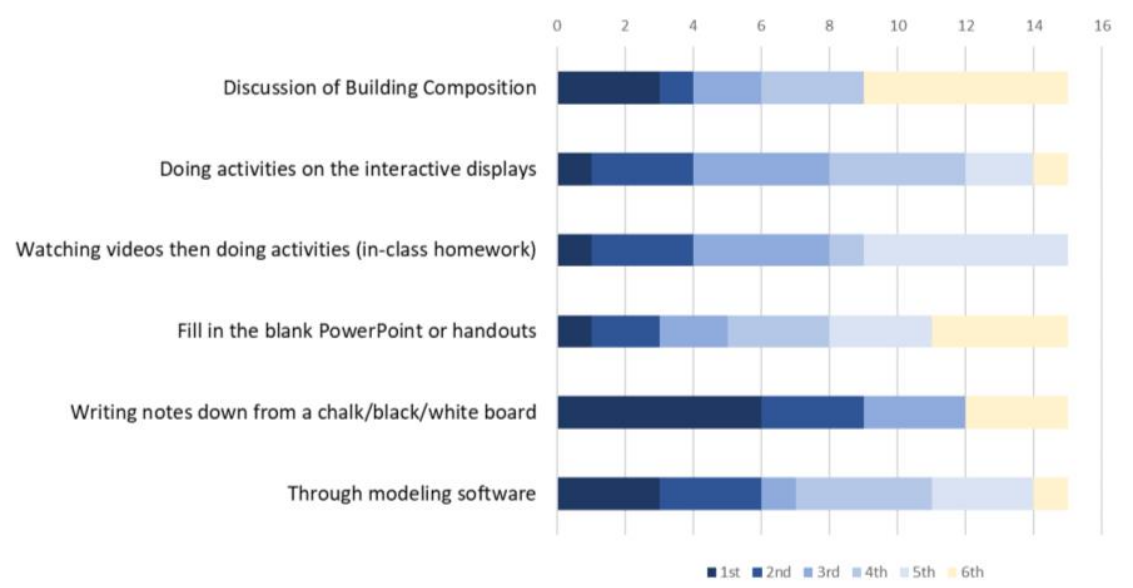

Figure 8: Ranking of Preferred Teaching Methods

\section{Flipped Lecture Participation}

With potential difficulties in getting students to watch videos out-of-class, the researcher looked into the data on how many times students viewed the lectures given the capability of Edpuzzle to track it based on Fogarty's (2017) success. In total there were 4 videos given (Table 6). The percentage of students who watched the videos and answered all video questions ranged from 73-91\% (before class) to 95\%-100\% (by end of semester), depending on the video. As the flipped portion progressed, less students watched the notes before class (18\% drop over the 4 videos). Over the course of the semester, the average number of times to complete videos per student ranged from 1 to 2 times, after first video though, no one watched any a second time complete time. Out of the 22 students, many watched part of the videos more than once (Table 6). Table 6 shows that as the videos progressed in the composite segment of the class, less students watched video segments beyond one extra time. The average rewatch rate was between $22.7 \%$ to $50 \%$.

Table 6: EDpuzzle Light Board Watched Data

\begin{tabular}{|l|c|c|c|c|c|c|c|c|c|c|}
\hline \multirow{2}{*}{ Lecture } & \multicolumn{3}{|c|}{ Average Watched } & \multicolumn{4}{c|}{ Students vs. average times each video was watched } \\
\cline { 2 - 12 } & $\begin{array}{c}\text { Prior to } \\
\text { Class }\end{array}$ & \multirow{2}{*}{$\begin{array}{c}\text { End of } \\
\text { Semester }\end{array}$} & \multicolumn{4}{c|}{ Complete watches } & \multicolumn{3}{c|}{$\begin{array}{c}\text { Partial watches beyond } \\
\text { Complete }\end{array}$} \\
\cline { 4 - 12 } & & & 1 & 2 & 3 & $4+$ & 1 & 2 & 3 & $4+$ \\
\hline Composite Action & $20(91 \%)$ & $22(100 \%)$ & 21 & 1 & 0 & 0 & 11 & 1 & 0 & 1 \\
\hline Composite Design & $20(91 \%)$ & $22(100 \%)$ & 22 & 0 & 0 & 0 & 10 & 3 & 1 & 4 \\
\hline Stud Design & $18(82 \%)$ & $22(100 \%)$ & 22 & 0 & 0 & 0 & 5 & 0 & 0 & 0 \\
\hline Composite Deflections & $16(73 \%)$ & $21(95 \%)$ & 21 & 0 & 0 & 0 & 11 & 1 & 0 & 0 \\
\hline
\end{tabular}

\section{Perceived Notions of Confidence Levels}

To measure students' perceived confidence in their ability in completing structural steel tasks, 14 different tasks relating to various structural steel areas were identified. Relating back to the technologies adopted, the following questions correspond closely with technology:

- Q4: Recognize structural systems within larger contexts (solstice pods) 
- Q5: Identify factors that positively/negatively impact selection of structural steel systems (smartboard interaction)

- Q9: Ability to formulate a logical load path through a building (smartboard interaction)

- Q10: Calculate steel member capacities (Light board and Enhanced projection)

- Q14 Design optimum steel members for capacity (Light board and Enhanced projection)

As seen in Figure 9, the 5 questions increased with an average range between 1.87 and 3.47 and an overall average across all question with 2.21. In looking at the change in the pre-post score distributions for the 5 questions, positive attributes are noticed (Figure 10). For Solstice pod technology (Q4), it decreased the limited ability by 7 students and increased the certainty by 9 students, though only 2 said they can do with high certainty. For smart board interaction (the design charrettes) Q5 and Q9 yielded similar trends and magnitudes to that of Solstice pods (decreased 7-8 and increased 6-9). While Q9 did have the $2^{\text {nd }}$ highest amount of highly certain they could create a logical load path based on their interaction with technology. With regards to Light board and Enhanced white board projections, Q10 and Q14 had the largest changes. Here, limited ability was decreased between 7-12 and increased the higher certainty between 10-11 students. Topical discussion is mentioned later as different combinations of methods were merged into a single response for Q10 and Q14.

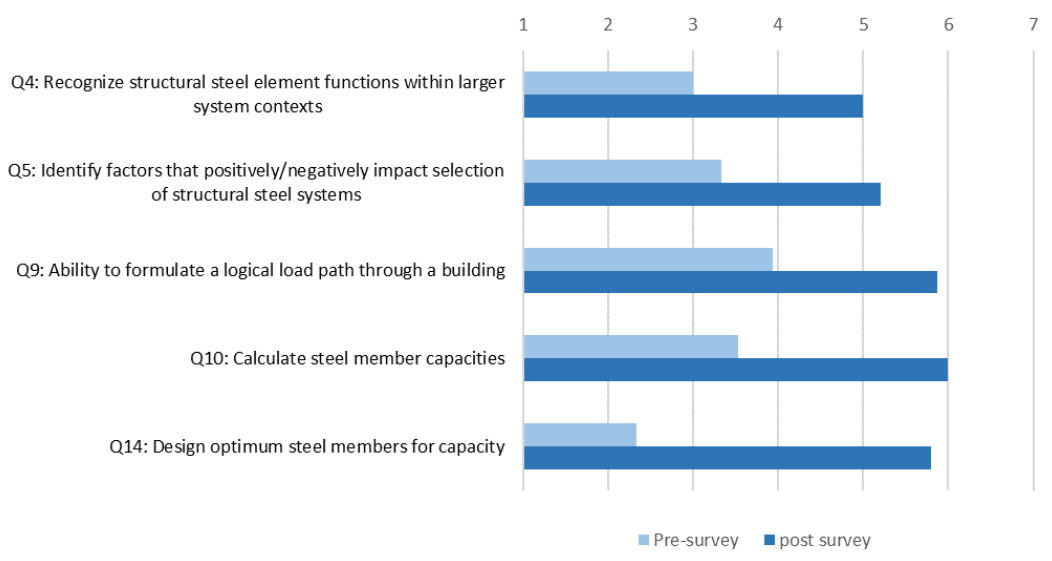

Figure 9: Average Response changes in confidence level

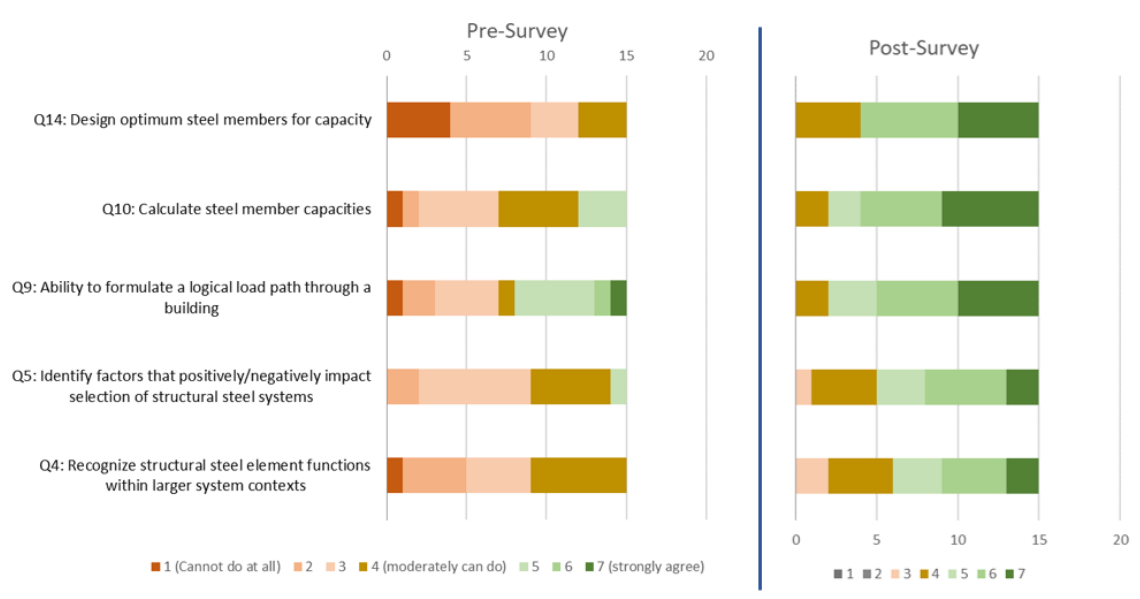

Figure 10: Likert Scale Response Changes for Confidence Level 


\section{Perceived Notions of Level of Knowledge}

Knowledge of the class topics was asked at the beginning and end of the semester. While there were 20 topics, only 5 were related to the adopted technologies. As such only these 5 questions are mentioned here:

- Q3: Load path and distribution throughout the structure (smartboard interactions)

- Q5: Identify factors that positively/negatively impact selection of structural steel systems (smartboard interactions)

- Q9: Ability to formulate a logical load path through a building (smartboard interactions)

- Q10: Calculate steel member capacities (Light board and Enhanced projection)

- Q14 Design optimum steel members for capacity (Light board and Enhanced projection)

While was logical that student knowledge would increase from taking their first steel design class, the pilot studied the average increase on the technology delivery topics compared to the traditional lectures. It was very evident in the pre to post comparison average ratings that there was significant increases in certain areas (Figure 11). Technology area increased averages were between 3.73 to 6.73 points while traditional learning had increased averages between 2.80 to 6.13 points. The largest average changes where with the light board composite beam lectures and the enhanced projection with metal deck lectures. Figure 12 supports a significant change in perceived knowledge. An area of caution that was observed in the responses was that students relayed an increase in knowledge of vibrations, P-Delta, lateral systems, and diaphragms. The reason this caution is that these topics were not covered in any material within AE 401. Because of this, all of the perceived knowledge results could be skewed. Reasons for this are unknown as the other structural classes do not cover these topics, excluding lateral MF analysis with slope deflection and moment distribution. A possible explination is that these could have been mentioned in passing in other classes.

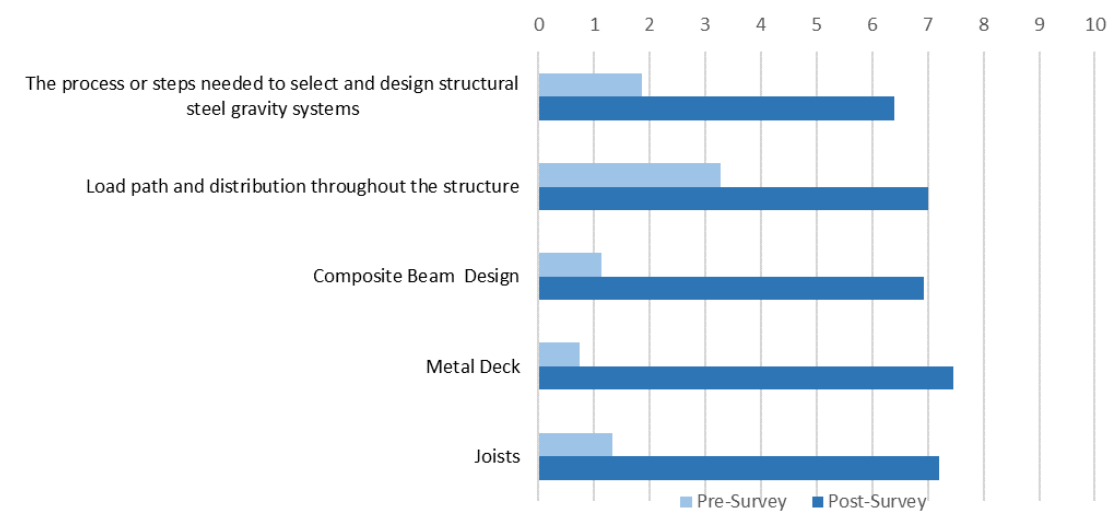

Figure 11: Average Response Changes in Topical Knowledge Level. 

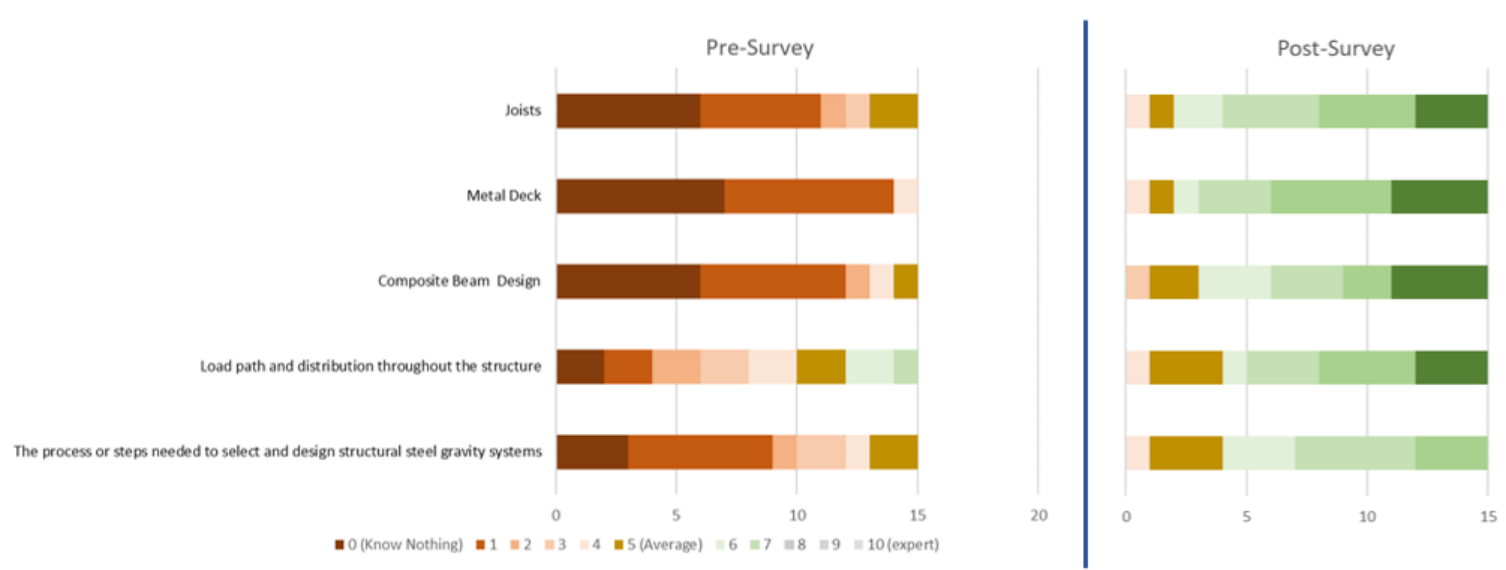

Figure 12: Likert Scale Response Changes for Knowledge Level

\section{Perceived Learning vs. Actual Performance}

Using Pearson's Correlation (r) Analysis, the author looked at several combinations of data to identify possible trends between actual performance, technology, and perceived abilities. From a topical knowledge standpoint with the 5 categories, the $\mathrm{r}$ values for each were: Composite Beams ( $\mathrm{r}=$ $+0.35)$, process to select a gravity system $(\mathrm{r}=+0.43)$, Metal Deck $(\mathrm{r}=0.71)$, Joists $(\mathrm{r}=-0.07)$, and Load Path $(\mathrm{r}=+0.67)$. All of the topical areas had a positive correlation except for Joists. Composite beams and gravity system selection had a medium positive effect while metal deck and load path had a really high correlation.

From a confidence standpoint, students' reported end confidence was compared to actual performance on problems relating to that topic. With recognizing structural systems within larger contexts (using solstice pods) had an $\mathrm{r}=+0.13$. An $\mathrm{r}=0.22$ is associated with being able to identify factors that positively/negatively impact selection (smartboard interactions). In designing optimum steel members (Light board and Enhanced white board projection) the $r$ was very small $(r=0.05)$. In looking at these three values and their associated technology there was not a strong correlation between them. In regards to having an ability to formulate a logical load path through a building (smartboard interactions), the correlation was high $(\mathrm{r}=0.59)$ and for being able to calculate steel member capacities (Light board and Enhanced white board projection) the effect size was also high ( $\mathrm{r}=0.51)$.

\section{Technology Discussion}

Based on the results from the study presented at the time and for depth that this project was undertaken there are several clear takeaways to improve upon for a wider adoption. From a preferred teaching method standpoint, students didn't vary much from their initial ways of thinking. Most still prefer chalk/whiteboards over the more interactive media. Factors for this could be familiarity with the traditional or a lack of interest in trying new methods. The amount of time that was given to the different topics and associated technologies also should be considered in future studies to see if more lectures are done that way increase interest and performance.

Enhanced white board projections did see a positive impact, more so for the deck lectures rather than the joist lectures. Students like being able to see the instructor interact with the tables the same way they would and have the example right beside it. A reason for the joist effectives to be lower than 
the deck was the fewer amount of examples and tables used. Light board videos as part of the classroom flip had positive reviews and critiques, with data to support the findings. From a knowledge of and a confidence in designing members, these light board results had a high correlation and high pre-postaverage jump. That said, it was also identified in the data that light boards didn't provide enough detail to convey confidence in optimizing such members. Part of this split could be the focus on: the lecture videos, a lack of optimizing discussions, and the way in which the examples/in-class activities were constructed. A common open-ended response was that of all of the edpuzzle methods, the light boards were best as students felt like they were watching the instructor teach as if they were in classroom (59\% said this). A critique on this method was actually in the instructor shirt color. They recommended a darker shirt. This was commented on as when the instructor was standing in front of the written text, students could not easily view the content until the instructor moved. Students like listening to actual projects being described by professionals (NASCC videos) on edpuzzle. They didn't like the length of those videos and the one other video given that was more theory based and less application.

Solstice pod activities of sharing content was given limited effort by students and was it very hard to get students continuously engaged with this method. Between the technology issues on getting the pods to run, having students bring correct technology to connect with the pods, and its unintended result in slowing down class time indicated that is it not a good technique for a class like this, at least in the way it was used here. Lastly, the interactive smartboard design charrette had a minimized correlation to actual performance yet, students really enjoyed the opportunity to try laying out bay designs then seeing the real designs. They did comment on having more discussion time on why the actual design was like it was so they could connect back to their solutions more. They also felt there were too many floors and that they rushed it, so cutting back on volume is recommended. Load path portion of the charrettes had a high increase and a strong correlation that was also conducted on the interactive smartboards.

In regards to the technology adoption mention, another aspect to consider is the creation and delivery of the content in a course. For perspective, the instructor first adopted these technologies for the study. Two prior offerings of a traditional chalkboard lecturing was done by the same instructor. The solstice pod activities required minimal effort for the instructor as there exists plenty of articles for students to find. Also the enhanced whiteboard projections did not take significant time to make due to the examples were already made and charts available in digital format. Minor editing to make them be readable on the whiteboards were needed. The smartboard design charrettes did take about 10 hrs. to find viable floor plans and to clean them up (removed content to be readable) prior to the activity. Here, there was also more time spent talking to students and explaining concepts "on the fly" while students did the activities. While it took more class time, the benefit outweighed the delay.

Lastly, the light boards did take significant more time to generate ahead of time. First lectures needed to be written down through story boarding to ensure content fit properly on the light board. Then each video clip too about 5 min to write on the glass. From here about $10 \mathrm{mins}$ was needed to clean to glass due to the marker type required. Followed by video editing that was somewhat slow due to compression on the files. While light boards required heavy upfront work videos were structured that if they needed edited in the future then only small segments need edited. It is recommended that you not only plan on what you will write but also what you will say to keep video concise. 


\section{Conclusion}

To summarize, this study provided results that showed improvements in areas of enhanced learning with technology even though students still ranked their preferences in learning styles to be nearly the same from before to after the class. Students commented that in most methods they enjoyed being more active in the classroom beyond just copying down board notes.

While positive results were observed, there are improvements that can be made to the technology advancements. Solstice pods will not be used again less the technology becomes smoother and easier to operate or a better application can be found. Flipped videos will be refined for length and style (more light board and less voice over) in segments that are visual and have more detailed explanations. A restructuring of the activities for the smartboards is needed and encouraged by the students to allow for more depth while not being rushed. The enhanced white board projections will be kept and added to with AISC manual pages being the next logical component being added.

While some statistical testing was done, more research testing needs done. To do this additional data points in a deeper/longer study is required to see a better reflection of the technology. Regardless, the author recommends to others steel design instructors to try similar technologies; as long as, the material is planned ahead of time for ease of deployment and to always have a backup in the event the technology fails.

\section{References}

Abbott, R. and Penney, T. E. (2016). "Training in Collaboration Should Start in College." Engineering News-Record, (275) 26

Andersen, N., Yazdani, S., and Andersen, K. (2007). "Performance outcomes in engineering design courses.” J. Prof. Issues Eng. Educ. Pract., Forum, January 2007, 2-8.

Aparicio, A.C. and Ruiz-Teran, A.M. (2007). "Tradition and Innovation in Teaching Structural Design in Civil Engineering", Journal of Professional Issues in Engineering Education and Practice, 133(4), 340349

ASCE, (2008). Civil Engineering Body of Knowledge for the 21st Century; Preparing the Civil Engineer for the Future. Second Edition, Reston, VA, ASCE.

Bernold, L.E. (2005). "Paradigm Shift in Construction Education is Vital for the Future of our Profession." Journal of Construction Engineering and Management, 131, 533-539.

Boud, D., and Feletti, G.E. (1997). The Challenge of Problem-Based learning, London: Kogan Paul.

Bruhl, J.C., Klosky, J.L., Mainwaring, T., and Hanus, J.P. (2017). "Accelerating the Development of Engineering Judgment in Students through Inquiry-Based Learning Activities.” 19022 Proceedings of the ASEE Annual Conference \& Exposition, 2017.

Davis, M. (2012). “A Plea for Judgment," Science and Engineering Ethics, 18(4), 789-808

DeGrazia, J.L., John L. Falconer, Garret Nicodemus, and Will Medlin (2012). Incorporating screencasts into chemical engineering courses. Proceedings of the ASEE Annual Conference \& Exposition, 2012.

Dymond, B.Z. and Swenty 2017. (2017). "horizontal Integration of the same design project in multiple structural engineering courses."

Fogarty, J.E. (2017). “Assessment of Flipped Classroom in Upper-Level Engineering Course.” Proceedings of the ASEE Annual Conference \& Exposition, 2017.

Fox, A.B., Jonathan Rosen, and Mary Crawford. CyberPsychology \& Behavior. February 2009, 12(1): 5153. https://doi.org/10.1089/cpb.2008.0107

Glover, D., Miller, D., Averis, D., and Door, V. (2007). "The evolution of an effective pedagogy for teachers using the interactive whiteboard in mathematics and modern languages: an empirical analysis from the secondary sector," Learning, Media and Technology, 32:1, 5-20. 
Grant, D.M., Malloy, A.D. \& Murphy, M.C. (2009). A Comparison of Student Perceptions of their Computer Skills to their Actual Abilities. Journal of Information Technology Education: Research, 8, 141-160. Informing Science Institute.

Hartley, J. and. Davies, I.K. (1978), "Note-taking: A critical review." Programmed Learning and Educational Technology Vol. 15, Iss. 3, 1978

Johnson, M. D., Narayanan, A. and Sawaya, W. J. (2013), Effects of Course and Instructor Characteristics on Student Evaluation of Teaching across a College of Engineering. J. Eng. Educ., 102: 289-318.

Kwuimy, C.A.K., Chen, Y., Jeff Kastner and Jason C. Heikenfeld A first time flipped classroom experience: Measure of outcomes and challenges Graham Brent Johnson. Student perceptions of the flipped classroom. PhD thesis, The University of British Columbia, 2013.

Margulieux, L., McCracken, W., Bujak, K., and Majerich, D.(2014) "Hybrid, Blended, Flipped, and Inverted: Defining Terms in a Two Dimensional Taxonomy," Proc. Of HICE Conference, Honolulu, HI

Mayo, M.J. (2009). "Video Games: A Route to Large-Scale STEM Education?” Science, Vol. 323, Issue 5910, pp. 79-82

Means, B. Evaluation of evidence-based practices in online learning: A meta-analysis and review of online learning studies.U.S. Department of Education, Office of Planning, Evaluation, and Policy Development. (2009).

Moon, S.K. (2010). "Design-Oriented Structural Engineering Education", 19th Analysis \& Computation Specialty Conference, 387-395

Penrod, J. (2005). A Method to Demonstrate the Importance of Homework, Innovations in Engineering Education, Mechanical Engineering Department Heads, v. 2005

Phelps, A., Sliger, L., Degracia, S., and Ganzerli, S. (2008). "Integration of New Teaching Methodologies into a Laboratory Based Course." 18th Analysis and Computation Specialty Conference, 1-11.

Prince, M. Does active learning work? A review of the research. J. Eng. Educ. 93, 3, 223-231 (2004).

Rafiq, Y. (2010). "A Radical Rethink in Educating Engineering Students", 19th Analysis \& Computation Specialty Conference, 366-376.

Savin-Baden, M. (2003). Facilitating Problem-Based Learning: Illuminating Perspectives. Berkshire, England: SRHE and Open University Press.

Schmidt, D.E., Sanchez, D., and Dickerson, S.J. (2017). "Increasing Student Engagement and Motivation by Replacing Homework with Assignment-Quizzes." \#19871Proceedings of the ASEE Annual Conference \& Exposition, 2017.

Schokker, A.J. and Scanlon, A. (2001). "Integration of Analysis and Design in the Structural Engineering Curriculum." Proceedings of the 2001 ASEE Annual Conference \& Exposition, 1-8

U.S. Department of Education (2001). "The Context of Postsecondary Education. The Condition of Education," NCES 2001072, National Center for Education Statistics, U.S. Department of Education, Washington, DC, 74-84.

Young, B., Ellobody, E., and Hu, T.W.C. (2012). "3D Visualization of Structures Using Finite-Element Analysis in Teaching." Journal of Professional Issues in Engineering Education \& Practice, 138(2), $131-138$. 